\title{
ANALISIS PEMBIAYAAN KESEHATAN BERSUMBER PEMERINTAH DI KOTA SERANG TAHUN 2014 - 2016
}

\author{
HEALTH FINANCING ANALYSIS SOURCED GOVERNMENT IN SERANG CITY \\ YEAR 2014 - 2016ITLE \\ Estherlina Sitorus ${ }^{1}$, Atik Nurwahyuni ${ }^{2}$ \\ 'Departemen Administrasi Kebijakan Kesehatan,Fakultas Kesehatan Masyarakat Universitas \\ Indonesia \\ ${ }^{2}$ Departemen Administrasi Kebijakan Kesehatan,Fakultas Kesehatan Masyarakat Universitas \\ Indonesia
}

\begin{abstract}
Background:This study aims to obtain information about health financing based on sources and utilization of funds derived from the government in Serang City year 2014-2016, as well as commitment from the local government of Serang City towards health financing by using approach District Health Account (DHA The results showed that the total budget for health financing funded by the government in Serang City from 2014-2016 has increased in 2014 amounting to $R p 61,759,128,963$, in year 2015 it was amounting to $\mathrm{Rp} 77,302,110,763$ and in year 2016 of Rp 88,278,652,111. The proportion of APBD Serang City in the Year 2014 was $6.02 \%$, Year 2015 was $6.99 \%$ and Year 2016 was $7.79 \%$. This shows the commitment of Serang City government to funding the health sector. From the perspective of Health financing by function, the largest percentage is health system governance functions and for curative services. From the perspective of the program, many is allocated for health system strengthening program $59,55 \%-67,43 \%$. While from the perspective of budget, most is allocated for the operationa expense $(83.68 \%-93.57 \%)$. With limited resources while increasing health needs, it will require the efficient use of existing resources as well as the selection of effective health program activities, and the need to make health budgeting policy as the basis or reference of health budget planning in Serang City.
\end{abstract}

Keywords: Health Financing, DHA, Health Expenditure

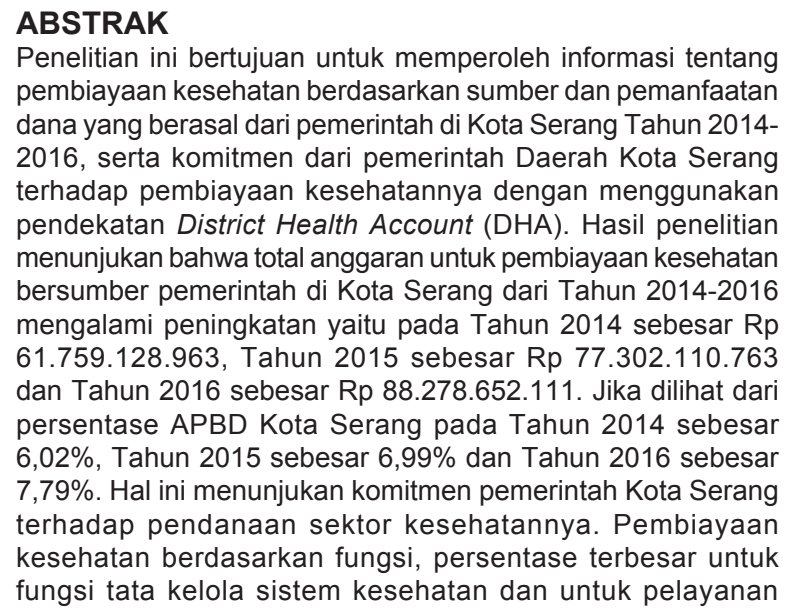

\section{ABSTRAK} dana yang berasal dari pemerintah di Kota Serang Tahun 2014 2016, serta komitmen dari pemerintah Daerah Kota Serang terhadap pembiayaan kesehatannya dengan menggunakan pendekatan District Health Account (DHA). Hasil penelitian menunjukan bahwa total anggaran untuk pembiayaan kesehatan bersumber pemerintah di Kota Serang dari Tahun 2014-2016 61.759.128.963, Tahun 2015 sebesar Rp 77.302110 .763 dan Tahun 2016 sebesar Rp 88.278.652.111. Jika dilihat dari persentase APBD Kota Serang pada Tahun 2014 sebesar 6,02\%, Tahun 2015 sebesar 6,99\% dan Tahun 2016 sebesar $7,79 \%$. Hal ini menunjukan komitmen pemerintah Kota Serang fungsi tata kelola sistem kesehatan dan untuk pelayanan kuratif. Berdasarkan program, banyak terealisasi untuk program penguatan Sistem kesehatan 59,55\%-67,43\%, berdasarkan mata anggaran, paling besar untuk belanja operasional (83,68\%$93,57 \%$ ). Dengan sumber daya yang terbatas sedangkan kebutuhan kesehatan yang terus meningkat, maka diperlukan efisensi penggunaan sumber daya yang ada serta pemilihan program kegiatan kesehatan yang efektif, serta perlunya dibuat kebijakan penganggaran kesehatan sebagai dasar atau acuan perencanaan anggaran kesehatan di Kota Serang.

Kata Kunci: Pembiayaan Kesehatan, DHA, Belanja Kesehatan

\section{Pendahuluan}

Universal Health Coverage (UHC) bertujuan untuk memastikan setiap orang, dimanapun bisa mendapatkan pelayanan kesehatan yang berkualitas tanpa menimbulkan masalah keuangan akibat penyakit yang dideritanya. Setiap tahunnya 100 juta orang jatuh miskin dan 150 juta orang secara global mengeluarkan biaya kesehatannya secara pribadi (out of pocket) untuk biaya kesehatannya. Jaminan kesehatan adalah inti dari Universal Health Coverage dan meningkatkan pembiayaan kesehatan adalah tujuan utama kebijakan pembiayaan kesehataan. ${ }^{1}$

Sistem Pembiayaan kesehatan sangat penting untuk mencapai Universal Health Coverage, dengan sistem pembiayaan kesehatan dapat meningkatkan pendanaan untuk kesehatan dan penggunaan dana kesehatan secara efisien dan efektif.

Menurut Sekretaris Jenderal Kementrian Kesehatan, anggaran fungsi kesehatan dalam Anggaran Pendapatan dan Belanja Negara (APBN) Tahun 2016 mengalami kenaikan menjadi 5,05\% atau sebesar Rp 109 triliun bila dibandingkan Tahun 2015 sebesar Rp 75 triliun (3,45 \% dari APBN). Sedangkan berdasarkan data kesehatan dunia Tahun 2014 (World Health Report 2014) 
dalam pendanaan kesehatan negara-negara di Asia Tenggara, Singapura adalah negara di Asia Tenggara yang mengalokasikan biaya kesehatan tertinggi $14 \%$ PDB, disusul Thailand (13\%) dan Vietnam(13\%).

Pembangunan bidang kesehatan merupakan bagian yang tidak dapat dipisahkan dari pembangunan nasional ataupun pembangunan daerah. Kesehatan merupakan hak asasi dan investasi serta tanggung jawab bersama, oleh karena itu perlu perhatian khusus dan kerjasama semua pihak atau lintas sektor guna mewujudkan derajat kesehatan yang optimal dari masyarakat.

Untuk meningkatkan derajat kesehatan suatu masyarakat menurut World Health Organization (WHO) diperlukan anggaran minimal 5\% - 6\% dari total APBN suatu negara, sedangkan untuk mencapai derajat kesehatan yang ideal diperlukan anggaran 15\% - 20\% dari APBN. Anggaran yang cukup besar tersebut memang diperlukan karena biaya kesehatan yang cukup tinggi sedangkan kesehatan tetap harus menjadi prioritas karena merupakan investasi guna meningkatkan derat kesehatan dan produktivitas warganya.

Tingkat kesejahteraan nasional yang diukur berdasarkan gross domestic bruto sangat berhubungan erat dengan pembiayaan kesehatannya. Semakin besar tingkat pendapatan perkapitanya, semakin besar pula pembiayaan kesehatannya. Berdasarkan penelitian yang dilakukan oleh World Health Organization (WHO) Tahun 2012 bahwa peningkatan pembiayaan kesehatan mempunyai korelasi dengan derajat kesehatan yang lebih baik. ${ }^{1}$

Berdasarkan Undang-undang No. 23 Tahun 2014 tentang Pemerintahan Daerah memberikan kewenangan kepada Pemerintahan Daerah untuk mengatur dan mengurus sendiri urusan pemerintahan menurut asas otonomi dan tugas pembantuan yang diarahkan untuk mempercepat terwujudnya kesejahteraan masyarakat melalui peningkatan pelayanan, pemberdayaan, dan peran masyarakat. Disamping itu melalui otonomi, daerah diharapkan mampu meningkatkan daya saing daerah dengan memperhatikan prinsip demokrasi, pemerataan, keadilan dan kekhasan suatu daerah dalam Sistem Negara Kesatuan Republik Indonesia.

Dalam pelaksanaan desentralisasi tidak terlepas dari berbagai masalah yang timbul diantaranya kurangnya komitmen Pemerintah Daerah dalam pembangunan kesehatan, masih kurangnya pelayanan bagi penduduk miskin serta kurangnya kemampuan staf daerah serta. Selain masalah tersebut masalah kualitas dan pembiayaan pelayanan kesehatan. Sektor kesehatan tentunya akan bersaing dengan sektor lain supaya memperoleh alokasi dana yang cukup untuk program pelayanan bagi masyarakat.

Sehubungan dengan pelaksanaan otonomi daerah, pada Tahun 2000 telah disepakati antara Menteri Kesehatan dengan para bupati/walikota se-Indonesia agar mengalokasikan sedikitnya 15 pesen dari APBD untuk biaya kesehatan, sedangkan berdasarkan analisis yang dilakukan pada Tahun 2001 menunjukkan bahwa sektor kesehatan masih belum menjadi prioritas di daerah yaitu dengan terlihatnya belanja kesehatan di 22 kabupaten/kota baru mencapai 5,3 persen masih jauh dari angka 15 persen seperti yang sudah disepakati oleh para bupati/walikota. Hanya dua kabupaten yang alokasi belanja kesehatannya lebih dari 10 persen yaitu Kabupaten Deli Serdang, Sumut (10,7 persen) dan Kabupaten Gorontalo (13,2 persen). ${ }^{2}$

Untuk mengetahui efisiensi sektor kesehatan di berbagai wilayah diperlukan adanya studi tentang pembiayaan dan pembelanjaan kesehatan. Tujuan akhir dari studi pembiayaan diharapkan dapat digunakan dalam pembahasan pencarian alternatif sumber-sumber keuangan serta melengkapi informasi untuk perencanaan anggaran kedepannya. $^{3}$

Menurut Peraturan Presiden Republik Indonesia No 72 Tahun 2012 tentang Sistem Kesehatan Nasional (SKN) menyebutkan bahwa dalam Sistem Kesehatan Nasional (SKN), pembiayaan kesehatan merupakan salah satu sub sistem dalam SKN, sehingga dapat menjadi acuan dalam penyusunan dan pelaksanaan pembangunan kesehatan yang dimulai dari kegiatan perencanaan sampai dengan kegiatan monitoring dan evaluasi.

Pembiayaan kesehatan di era desentralisasi ini sangat tergantung pada komitmen daerah, khususnya pada pembiayaan yang bersumber dari pemerintah. Sistem pembiayaan kesehatan di daerah perlu dikembangkan agar isu pokok dalam pembiayaan kesehatan daerah yaitu mobilisasi, alokasi, dan efisiensi pembiayaan dapat terlaksana dengan baik, sehingga menjamin pemerataan, mutu dan keseimbangan pembangunan kesehatan daerah. ${ }^{4}$

Informasi biaya dari akuntansi keuangan kabupaten/kota melalui pendekatan District Health Account (DHA) ini dapat memberikan gambaran hasil kegiatan yang sudah dilakukan apakah sudah sesuai dengan yang diharapkan, serta memberikan gambaran terkait mobilisasi alokasi 
Tabel 1

Realisasi Pendapatan dan Belanja Dinas Kesehatan Kota Serang Tahun Anggaran 2013-2015

\begin{tabular}{lrrr}
\hline Komponen Pendapatan & \multicolumn{1}{c}{$\begin{array}{c}2013 \\
(\mathrm{Rp})\end{array}$} & \multicolumn{1}{c}{$\begin{array}{c}2014 \\
(\mathrm{Rp})\end{array}$} & \multicolumn{1}{c}{\begin{tabular}{c}
\multicolumn{1}{c}{$(\mathrm{Rp})$} \\
\end{tabular}} \\
\hline Pendapatan Asli Daerah & 65.376 .087 .425 & 97.827 .597 .434 & 111.062 .806 .774 \\
Dana Perimbangan & 600.180 .687 .989 & 648.709 .803 .905 & 670.172 .308 .659 \\
Lain-lain Pendapatan Daerah Yang Sah & 203.775 .791 .455 & 277.974 .901 .628 & 324.423 .685 .156 \\
Jumlah Pendapatan Daerah & $\mathbf{8 6 9 . 3 3 2 . 5 6 6 . 8 6 9}$ & $\mathbf{1 . 0 2 4 . 5 1 2 . 3 0 2 . 9 6 7}$ & $\mathbf{1 . 1 0 5 . 6 5 8 . 8 0 0 . 5 8 9}$ \\
Belanja Dinas Kesehatan & $\mathbf{4 7 . 4 0 3 . 1 6 2 . 1 1 1}$ & $\mathbf{6 1 . 1 3 4 . 7 7 7 . 0 0 9}$ & $\mathbf{7 6 . 2 4 9 . 9 5 7 . 2 6 3}$ \\
Belanja Dinas Kesehatan & 5,45 & 5,97 & 6,89 \\
\hline
\end{tabular}

Sumber : LKPJ 2013-2015 dan Laporan Realisasi Dinas Kesehatan Kota Serang Tahun 2013-2015

sumber-sumber ekonomi yang dapat menghasilkan sumber ekonomi lain. ${ }^{5}$

Berdasarkan laporan akhir penilaian kualitas belanja daerah urusan kesehatan Provinsi Banten perhitungan menggunakan Provincial Health Account (PHA), presentase belanja kesehatan di Provinsi Banten masih kurang dari 10 persen $(3,43 \%)$. Rendahnya persentase belanja kesehatan Provinsi Banten terhadap kesehatan ini menunjukkan indikasi masih rendahnya komitmen daerah terhadap pembangunan kesehatannya. Di tingkat kabupaten/kota dari 4 kabupaten/kota yang dianalisis untuk Kabupaten Tanggerang, Kota Tanggerang dan Kota Cilegon, belanja kesehatan per kapita sudah mencukupi jumlah belanja kesehatan yang direkomendasikan oleh WHO tahun 2015 yaitu sebesar $\$ 60$ atau Rp 780.000. Sedangkan untuk kabupaten Pandeglang belanja kesehatannya masih kurang dari jumlah yang direkomendasikan WHO. ${ }^{6}$

Kota Serang merupakan salah satu dari delapan kabupaten/kota yang berada di Provinsi Banten yang mempunyai kedudukan sebagai ibu kota Provinsi Banten. Dengan perkembangan pembangunan daerah, kondisi perekonomian kota Serang setiap tahunnya mengalami perkembangan dan pertumbuhan yang positif. Untuk Belanja Kesehatannya Kota Serang masih dikelola oleh Dinas Kesehatan Kota Serang saja karena belum adanya Rumah Sakit Umum milik Pemerintah Kota Serang.

Apabila dilihat dari capaian indikator Standar Pelayanan Minimal (SPM) pada urusan kesehatan Kota Serang Tahun 2015 masih ada beberapa capaian yang dibawah target yang ditetapkan diantaranya pada pelayanan kesehatan dasar yaitu cakupan ibu hamil K4 71, 49\% dari target sebesar $95 \%$, cakupan komplikasi kebidanan yang ditangani $55,43 \%$ dari target $80 \%$, cakupan pelayanan anak balita $47,12 \%$ dari target $90 \%$, cakupan neonates dengan komplikasi yang ditangani $20,07 \%$ dari target $80 \%{ }^{7}$
Berdasarkan latar belakang diatas terlihat bahwa alokasi pembiayaan kesehatan di Kota Serang masih dibawah standar yang ditetapkan sesuai dengan Undang-undang nomor 36 Tahun 2009 tentang Kesehatan Pasal 171 yang menyatakan bahwa besar anggaran kesehatan pemerintah dialokasikan minimal sebesar $5 \%$ dari APBN diluar gaji, dan besar anggaran kesehatan pemerintah daerah provinsi, kabupaten dan kota dialokasikan minimal sebesar $10 \%$ dari APBD diluar gaji. Serta masih belum berjalannya program-program kesehatan yang ada secara maksimal dilihat dari capaian indikator kinerja SPM pada urusan kesehatan Kota Serang masih ada yang dibawah target yang ditetapkan.

Pendanaan kesehatan di Kota Serang yang bersumber Pemerintah belum didukung dengan data mengenai jumlah total dana yang disediakan untuk membiayai sektor kesehatan, dan bagaimana penggunaan dana menurut sumbernya, pengelola dana, provider, fungsi, mata anggaran, dan penerima manfaat dari tiap kegiatan yang sudah dibiayai. Hal ini menyebabkan pengambilan kebijakan penyusunan alokasi anggaran ditahun berikutnya hanya menggunakan penganggaran alokasi tahuntahun sebelumnya dengan menaikkan sebesar persentase tertentu saja. Data anggaran kesehatan yang lengkap ini dapat diperoleh apabila pemerintah daerah melakukan analisa pembiayaan kesehatan di daerahnya.

Untuk dapat mengetahui bagaimana pembiayaan kesehatan oleh pemerintah, baik pemerintah pusat ataupun pemerintah daerah perlu dilakukan analisis pembiayaan kesehatan yang bersumber dari Anggaran Pendapatan dan Belanja Negara (APBN) dan Pendapatan dan Belanja Daerah (APBD) di Kota Serang, maka sangat penting dilakukan penelitian untuk menganalisis pemanfaatan pendanaan kesehatan Kota Serang yang bersumber pemerintah tahun anggaran 2014-2016, dengan menggunakan teknik analisis pembiayaan kesehatan daerah atau District Health Account (DHA). 


\section{Metode Penelitian}

Penelitian ini merupakan penelitian kualitatif dengan desain penelitian studi kasus, yang bertujuan menganalisa bagaimana pembiayaan kesehatan berdasarkan sumber dan alokasi dana yang berasal dari pemerintah di Kota Serang serta melakukan wawancara mendalam dengan pejabat terkait untuk mengetahui komitmen dari pemerintah Daerah Kota Serang terhadap pembiayaan kesehatannya.

Data pembiayaan kesehatan oleh pemerintah Kota Serang dianalisa dengan menggunakan pendekatan District Health Account (DHA).

\section{Hasil dan Pembahasan}

1. Gambaran Realisasi Pendapatan Kota Serang Tahun 2014 -2016

Berdasarkan tabel 2 dapat dilihat bahwa Pendapatan Kota Serang sebagian besar berasal dari Dana Perimbangan yaitu pada Tahun 2016 sekitar 72,91 \% dari total pendapatan di Kota Serang. Hal ini menunjukkan bahwa masih adanya ketergantungan daerah terhadap pendanaan dari pusat. Namun demikian Kota Serang berupaya untuk meningkatkan PAD (Pendapatan Asli Daerah)

Tabel 2

Realisasi Pendapatan Kota Serang Tahun 2014-2016

\begin{tabular}{|c|c|c|c|c|c|c|c|}
\hline \multirow{2}{*}{ No } & \multirow{2}{*}{ Pendapatan } & \multicolumn{6}{|l|}{ Tahun } \\
\hline & & 2014 (Rp) & $\%$ & 2015 (Rp) & $\%$ & 2016 (Rp) & $\%$ \\
\hline 1 & $\begin{array}{l}\text { Pendapatan } \\
\text { Daerah }\end{array}$ & 97.827 .597 .434 & 9,55 & 111.062 .806 .774 & 10,04 & 126.900 .900 .019 & 11,21 \\
\hline 2 & Dana Perimbangan & 648.709.803.905 & 63,32 & 670.172 .308 .659 & 60,61 & 825.491 .157 .313 & 72,91 \\
\hline \multirow[t]{2}{*}{3} & $\begin{array}{l}\text { Lain-lain pendapatan } \\
\text { Daerah Yang Sah }\end{array}$ & 277.974 .901 .628 & 27,13 & 324.423 .685 .156 & 29,34 & 179.874 .216 .258 & 15,89 \\
\hline & Jumlah & 1.024 .512 .302 .967 & 100 & 1.105 .658 .800 .589 & 100 & 1.132.266.273.590 & 100 \\
\hline
\end{tabular}

Sumber : LKPJ Walikota Serang Tahun 2014-2016

Tabel 3

Realisasi Belanja Kota Serang Tahun 2014-2016

\begin{tabular}{|c|c|c|c|c|c|c|c|}
\hline \multirow{2}{*}{ No } & \multirow{2}{*}{ Belanja } & \multicolumn{6}{|l|}{ Tahun } \\
\hline & & 2014 (Rp) & $\%$ & 2015 (Rp) & $\%$ & 2016 (Rp) & $\%$ \\
\hline 1 & $\begin{array}{l}\text { Belanja Tidak } \\
\text { Langsung }\end{array}$ & 484.739 .167 .740 & 51,03 & 508.982 .112 .134 & 37,93 & 555.587 .702 .548 & 49,17 \\
\hline \multirow[t]{2}{*}{2} & Belanja Langsung & 465.230.974.348 & 48,97 & 552.935 .680 .602 & 52,07 & 574.253 .624 .881 & 50,83 \\
\hline & Jumlah & 949.970 .142 .088 & 100 & 1.061 .917 .792 .736 & 100 & 1.129 .841 .327 .429 & 100 \\
\hline
\end{tabular}

Sumber : LKPJ Walikota Serang Tahun 2014-2016

Tabel 4

Gambaran Realisasi Belanja Kesehatan Kota Serang Tahun 2014-2016

\begin{tabular}{|c|c|c|c|c|c|c|c|}
\hline \multirow{2}{*}{ No } & \multirow{2}{*}{ Belanja } & \multicolumn{6}{|l|}{ Tahun } \\
\hline & & 2014 (Rp) & $\%$ & 2015 (Rp) & $\%$ & 2016 (Rp) & $\%$ \\
\hline 1 & Dinas Kesehatan & 61.134 .777 .009 & 98,99 & 76.249 .957 .263 & 98,64 & 87.332.397.119 & 98,92 \\
\hline 2 & $\begin{array}{l}\text { Badan } \\
\text { Pemberdayaan } \\
\text { Masyarakat, } \\
\text { Perempuan dan } \\
\text { Keluarga Berencana }\end{array}$ & 620.974 .000 & 1,00 & 1.015 .253 .500 & 1,31 & 870.354 .992 & 0,99 \\
\hline 3 & $\begin{array}{l}\text { Badan } \\
\text { Penanggulang } \\
\text { Bencana Daerah }\end{array}$ & 3.377 .950 & 0,01 & 0 & 0 & 0 & 0 \\
\hline \multirow[t]{2}{*}{4} & $\begin{array}{l}\text { Kecamatan } \\
\text { Kasemen }\end{array}$ & 0 & 0 & 36.900 .000 & 0,05 & 75.900 .000 & 0,09 \\
\hline & $\begin{array}{l}\text { Jumlah Belanja } \\
\text { Kesehatan }\end{array}$ & 61.759 .128 .963 & 100 & 77.302 .110 .763 & 100 & 88.278 .652 .111 & 100 \\
\hline
\end{tabular}


Tabel 5

Proporsi Pembiayaan Kesehatan Bersumber APBD Kota Serang Tahun 2014-2016

\begin{tabular}{ccclc}
\hline Tahun & Total APBD (Rp) & $\begin{array}{c}\text { Total Belanja } \\
\text { Bidang Kesehatan } \\
(\mathbf{R p})\end{array}$ & $\begin{array}{c}\text { Persentase (\%) } \\
\text { Bidang Kesehatan } \\
\text { Terhadap APBD }\end{array}$ & $\begin{array}{c}\text { Persentase (\%) } \\
\text { Bidang Kesehatan } \\
\text { Diluar Gaji }\end{array}$ \\
\hline 2014 & 1.024 .512 .302 .967 & 61.759 .128 .963 & $6,02 \%$ & $3,22 \%$ \\
2015 & 1.105 .658 .800 .589 & 77.302 .110 .763 & $6,99 \%$ & $4,53 \%$ \\
2016 & 1.132 .266 .273 .590 & 88.278 .652 .111 & $7,79 \%$ & $5,78 \%$ \\
\hline
\end{tabular}

Tabel 6

Pembiayaan Kesehatan Menurut Sumber Pembiayaan di Kota Serang Tahun 2014-2016

\begin{tabular}{|c|c|c|c|c|c|c|c|}
\hline \multirow{2}{*}{ No } & \multirow{2}{*}{ Sumber Biaya } & \multicolumn{6}{|l|}{ Tahun } \\
\hline & & 2014 (Rp) & $\%$ & 2015 (Rp) & $\%$ & 2016 (Rp) & $\%$ \\
\hline 1 & $\begin{array}{l}\text { FS.1.1.1.1.3. APBN Kementrian } \\
\text { Kesehatan: JKN (PBI) }\end{array}$ & 9.337 .050 .267 & 15,12 & 8.961 .505 .956 & 11,59 & 11.804 .298 .073 & 13,37 \\
\hline 2 & $\begin{array}{l}\text { FS.1.1.1.1.4. APBN Kementrian } \\
\text { Kesehatan : BOK/DAK-non Fisik }\end{array}$ & 1.414 .235 .000 & 2,29 & 1.464.257.000 & 1,89 & 3.383 .626 .000 & 3,83 \\
\hline 3 & $\begin{array}{l}\text { FS.1.1.1.1.9. APBN Kementrian } \\
\text { Kesehatan : selain DK, TP, JKN, } \\
\text { BOK }\end{array}$ & 3.523 .032 .125 & 5,71 & 3.773 .693 .500 & 4,88 & 5.115 .303 .625 & 5,79 \\
\hline 4 & $\begin{array}{l}\text { FS.1.1.2.9.9. APBN Kementrian } \\
\text { Lainnya }\end{array}$ & 0 & 0 & 3.609 .785 .500 & 4,67 & 68.600 .000 & 0,08 \\
\hline 5 & FS.1.1.2.1.1. APBD Provinsi & 0 & 0 & 3.740.263.209 & 4,84 & 1.816 .802 .000 & 2,06 \\
\hline \multirow[t]{2}{*}{6} & $\begin{array}{l}\text { FS.1.1.2.2.1. APBD Kabupaten/ } \\
\text { Kota }\end{array}$ & 47.484 .811 .571 & 76,88 & 55.752 .605 .598 & 72,13 & 66.090 .022 .413 & 74,87 \\
\hline & Grand Total & 61.759.128.963 & 100 & 77.302 .110 .763 & 100 & 88.278.652.111 & 100 \\
\hline
\end{tabular}

hal ini terlihat dari jumlah PAD yang semakin meningkat dari Tahun 2014-2016. Lain-lain pendapatan daerah yang sah diperoleh dari dana penyesuaian dan otonomi khusus dari Pemerintah Pusat dan bantuan keuangan dari Provinsi Banten.

2. Gambaran Realisasi Belanja Kota Serang Tahun 2014 -2016

Berdasarkan tabel 3 dapat dilihat jumlah belanja langsung dan belanja tidak langsung di Kota Serang. Persentase jumlah belanja langsung dan tidak langsung terhadap total belanja hampir sama besar, walupun untuk belanja langsung lebih banyak dari belanja tidak langsung. Hal ini dikarenakan belanja tidak langsung merupakan belanja yang tidak memiliki keterkaitan secara langsung dengan program dan kegiatan.

3. Gambaran Realisasi Belanja Kesehatan di Kota Serang Tahun 2014 - 2016

Dari Tabel 4 bisa terlihat bahwa belanja kesehatan paling banyak dikelola oleh Dinas Kesehatan selaku pelaksana urusan wajib kesehatan di Kota Serang. Kota Serang belum memiliki Rumah Sakit milik Pemerintah Daerah. Baru di Tahun 2017 mulai dianggarkan untuk pendirian Rumah Sakit milik Pemerintah Kota Serang.

4. Proporsi Pembiayaan Kesehatan Bersumber APBD Kota Serang Tahun 2014 - 2016

Berdarakan tabel 5 terlihat adanya kenaikan realisasi anggaran bidang kesehatan yang sejalan dengan peningkatan jumlah APBD di Kota Serang. Persentase pendanaan bidang kesehatan pada Tahun 2014 sebesar 6,02\% , pada Tahun 2015 sebesar 6,99\% dan di Tahun 2016 sebesar 7,79\%. Namun apabila dikurangi dengan belanja gaji maka persentase belanja kesehatan terhadap APBD hanya sebesar $3,22 \%$ di Tahun 2014, 4,53\% Tahun 2015, dan 5,78\% Tahun 2016.

5. Gambaran Pembiayaan Kesehatan Menurut Sumber Pembiayaan

Dari Tabel 6 dapat dilihat bahwa menurut sumber pembiayaan kesehatan di Kota Serang sekitar $70 \%$ berasal dari Anggaran Pendapatan Belanja Daerah (APBD). Selain dari APBD Kota Serang juga mendapatkan sumber pendanaan dari APBN berupa dana Jaminan Kesehatan Nasional (JKN), Dana Alokasi Khusus (DAK) fisik, DAK non Fisik dan Cukai Rokok. 
Berdasarkan data diatas maka dapat dihitung biaya kesehatan perkapita yang bersumber dari pemerintah di Kota Serang dengan cara membagi jumlah belanja kesehatan dengan jumlah penduduk Kota Serang. Belanja kesehatan yang bersumber pemerintah di Kota Serang pada Tahun 2014 sebesar Rp 100,622 pada Tahun 2015 sebesar Rp 123,995 dan Tahun 2016 sebesar Rp 140. 474. Jika dilihat dari setiap tahunnya mengalami peningkatan untuk belanja kesehatan perkapitanya.

Dari Tahun 2014-2016 sumber pendanaan kesehatan di Kota Serang paling besar berasal dari APBD Kota yaitu pada Tahun 2014 sebesar $76,88 \%$, Tahun 2015 sebesar $72,13 \%$ dan Tahun 2016 sebesar $74,87 \%$. Selain dari APBD sumber pendanaan Kesehatan Kota Serang berasal dari APBN Kementrian Kesehatan JKN(PBI), APBN Dana Alokasi Khusus (DAK) Non Fisik, APBN Dana Alokasi Khusus (DAK) Fisik, APBN dari Cukai Rokok dan APBD Provinsi.

Sumber APBN DAK Fisik yang cukup besar jumlahnya digunakan untuk pengadaan obat dan perbekalan kesehatan, Pengadaan Puskesmas Keliling, Pengadaan Sarana Pendukung seperti perbaikan rumah dinas dokter dan paramedis, serta Instalasi Pengolahan Air Limbah (IPAL). Untuk DAK non fisik berupa Bantuan Operasional Kesehatan (BOK) dan Akreditasi Puskesmas.

Dana yang bersumber dari APBN Cukai Rokok di gunakan untuk kegiatan survey rokok, pembahasan Raperda kawasan bebas asap rokok, pengadaan alat-alat kedokteran umum, dan pembuatan instalasi Pengolahan Air Limbah (IPAL) Puskesmas.
Menurut Undang-undang Nomor 17 Tahun 2003 tentang Keuangan Negara, Anggaran Pendapatan dan Belanja Daerah yang biasa disingkat APBD adalah suatu rencana keuangan tahunan pemerintah daerah yang disetujui oleh Dewan Perwakilan Rakyat Daerah. Jumlah APBD di Kota Serang yang semakin meningkat dari Tahun 2014 sebesar Rp 1.024.512.302.967 Tahun 2015 sebesar Rp 1.105.658.800.589 dan Tahun 2016 sebesar Rp 1.132.266.273.590, tapi jika dilihat dari komponen APBD yang terdiri atas Pendapatan Asli Daerah (PAD), dana perimbangan dan lain-lain pendapatan daerah yang sah, APBD Kota Serang masih di dominasi dari dana perimbangan yaitu sebesar $63,32 \%-72,91 \%$. Pendapatan Asli Daerah (PAD) hanya sekitar $9,55 \%-11,21 \%$, sedangkan untuk Lain-lain pendapatan daerah yang sah berupa dana bagi hasil pajak dari provinsi sekitar $15,89 \%-29,34 \%$. Perlu dilakukan upaya-upaya peningkatan PAD melalui intensifikasi dan ekstensifikasi penggalian potensi PAD, sehingga komponen PAD akan dapat memberikan kontribusi yang lebih besar terhadap APBD. ${ }^{8}$

Berdasarkan penelitian sebelumnya tentang Perencanaan Anggaran Kesehatan Melalui Kajian Pembiayaan Kesehatan Bersumber Pemerintah di Kabupaten Pidie Jaya, bahwa pembiayaan kesehatan terbesar bersumber dariAPBD sebesar $88 \%$, Kementrian Kesehatan 7,60\%, Kemensos: Program Keluarga Harapan 3,40\%, Kemendagri 1,00\%, diluar kementrian kesehatan lainnya sebesar $0,10 \% .{ }^{9}$ Menurut penelitian Pola Pendanaan Kesehatan Bersumber Pemerintah dan

Tabel 7

Pembiayaan Kesehatan Menurut Jenis Fungsi di Kota Serang Tahun 2014 - 2016

\begin{tabular}{llllllll}
\hline \multirow{2}{*}{ No Jenis Fungsi } & Tahun & & & & & \\
\cline { 2 - 7 } & $\mathbf{2 0 1 4}(\mathbf{R p})$ & $\mathbf{2 0 1 5}(\mathbf{R p})$ & $\mathbf{2 0 1 6}(\mathbf{R p})$ & \% \\
\hline 1 & HC.1. Pelayanan Kuratif & 16.475 .101 .037 & 26,68 & 19.505 .112 .489 & 25,23 & 24.820 .295 .400 & 28,12 \\
2 & HC.4. Layanan Penunjang & 1.093 .382 .000 & 1,77 & 2.002 .748 .350 & 2,59 & 302.704 .825 & 0,34 \\
3 & HC.5 Alat-alat/Bahan Medis & 3.382 .219 .015 & 5,47 & 5.444 .303 .287 & 7,04 & 6.239 .459 .899 & 7,07 \\
4 & $\begin{array}{l}\text { HC.6 Pelayanan Pencegahan } \\
\text { dan Kesehatan Masyarakat }\end{array}$ & 4.759 .747 .850 & 8.45 & 7.628 .308 .174 & 9,87 & 10.502 .771 .228 & 11,90 \\
$\begin{array}{l}\text { HC.7 Tata Kelola Sistem } \\
\text { Kesehatan dan Administrasi }\end{array}$ & 34.968 .772 .057 & 56.62 & 41.764 .449 .963 & 54,03 & 44.821 .820 .259 & 50,77 \\
$\begin{array}{l}\text { Pembiayaan Kesehatan } \\
\text { HC.9 Pelayanan Kesehatan di } \\
\text { Luar Klasifikasi Di Atas }\end{array}$ & 458.933 .000 & 1.00 & 957.188 .500 & 1,24 & 1.591 .600 .500 & 1,80 \\
\hline & & & & & & & \\
\hline
\end{tabular}


Komitmen Pemerintah Daerah Kabupaten Cirebon Tahun 2006, menunjukkan bahwa persentase terbesar sumber pendanaan kesehatan dari APBD Kabupaten yaitu sebesar $67,6 \%$, kemudian dari dana Askeskin sebesar $17,5 \%$ kemudian dari BLN/PLN yaitu sebesar $10,3 \% .^{10}$

6. Gambaran Pembiayaan Kesehatan Menurut Jenis Fungsi

Dari Tabel 7 dapat dilihat bahwa belanja kesehatan banyak digunakan untuk fungsi tata kelola sistem kesehatan dan administrasi pembiayaan kesehatan sekitar $50,77 \%$ $56,62 \%$, kemudian untuk pelayanan kuratif sebesar 25,23\%-28,12\%, kemudian untuk pelayanan pencegahan dan kesehatan masyarakat 8,45\%-11,90\% dan terakhir untuk alat-alat dan bahan medis sebesar Rp 5,47 $\%-7,07 \%$

Sesuai dengan Rencana Strategis (Renstra) Tahun 2015-2019 mengenai Program Indonesia Sehat Dengan Pendekatan Keluarga dijelaskan dalam Peraturan Pemerintah Kesehatan Republik Indonesia Nomor 39 Tahun 2016 tentang Pedoman Penyelenggaraan Program Indonesia Sehat Dengan Pendekatan Keluarga dimana disebutkan 4 (empat) area prioritas yaitu :

1. Penurunan angka kematian ibu dan bayi

2. Penurunan prevalensi balita pendek (stunting)

3. Penanggulangan penyakit menular dan

4. Penanggulangan penyakit tidak menular

Area prioritas sebagaiamana dimaksud diatas dilaksanakan dengan pendekatan upaya promotif dan preventif tanpa mengabaikan upaya kuratif dan rehabilitatif, sehingga sebaiknya program-program yang dilaksanakan mendukung fungsi promotif dan preventif. ${ }^{11}$

Dari analisa fungsi pembiayaan kesehatan di Kota Serang, pembiayaan kesehatan paling banyak terserap untuk fungsi tata kelola sistem kesehatan dan administrasi sistem kesehatan yaitu sebesar 50,77\%-56,62\%. Hal ini terlihat cukup besar dikarenakan kegiatan-kegiatan yang dilaksanakan banyak yang bersifat tata kelola sistem kesehatan dan administrasi seperti peningkatan sarana dan prasarana, revitalisasi sistem kesehatan, kegiatan yang bersifat pertemuan, pengkajian pengembangan lingkungan sehat, pendidikan dan pelatihan keterampilan petugas.

Fungsi pelayanan pencegahan dan kesehatan masyarakat mendapat porsi sebesar $8,45 \%-11,90 \%$ sangat kecil bila dibandingka program lainnya. Sebaiknya pendanaan sejalan dengan kerangka pendanaan Renstra 20152019 menekankan dua aspek utama dalam kerangka pendanaan yaitu : peningkatan pendanaan preventif \& promotif dan peningkatan efektivitas pembiayaan kesehatan. Peningkatan pendanaan preventif \& promotif diharapkan lebih cost effectiveness dibandingkan kuratif serta diharapkan setiap pembiayaan memenuhi kriteria cost effectiveness (investasi yang dikeluarkan memberikan manfaat dan daya ungkit yang besar) tepat guna dan hasil guna. ${ }^{12}$

7. Gambaran Pembiayaan Kesehatan Menurut Jenis Program

Dari tabel 8 dapat dilihat bahwa belanja kesehatan lebih banyak digunakan untuk program penguatan sistem kesehatan yang sifatnya capacity building/penunjang yaitu sekitar 59,55\% - 67,43\%. Untuk program yang bersifat Upaya Kesehatan Perorangan (UKP) sekitar 21,29\% - 26,49\%, kemudian untuk Upaya Kesehatan Masyarakat (UKM) sekitar $11,28 \%-15,74 \%$.

Jika dilihat dari program prioritas pembangunan kesehatan dalam Renstra Dinas Kesehatan Kota Serang Tahun 20142018 dimana program obat dan perbekalan

Tabel 8

Pembiayaan Kesehatan Menurut Jenis Program di Kota Serang Tahun 2014 - 2016

\begin{tabular}{|c|c|c|c|c|c|c|c|c|}
\hline \multirow{2}{*}{ No } & \multirow{2}{*}{ Jenis Program } & & \multicolumn{6}{|l|}{ Tahun } \\
\hline & & & 2014 (Rp) & $\%$ & 2015 (Rp) & $\%$ & 2016 (Rp) & $\%$ \\
\hline 1 & $\begin{array}{l}\text { PR.1. Program } \\
\text { Masyarakat }\end{array}$ & Kesehatan & 6.977 .822 .504 & 11,28 & 12.258 .336 .274 & 15,74 & 12.410 .917 .928 & 13,96 \\
\hline 2 & $\begin{array}{l}\text { PR.2 Program } \\
\text { Individu }\end{array}$ & Kesehatan & 13.140 .531 .067 & 21,29 & 18.810 .568 .439 & 25,02 & 23.234.678.725 & 26,49 \\
\hline \multirow[t]{2}{*}{3} & $\begin{array}{l}\text { PR.3 Program } \\
\text { Sistem Kesehatan }\end{array}$ & Penguatan & 41.640.775.392 & 67,43 & 46.233 .206 .050 & 59,24 & 52.633 .055 .458 & 59,55 \\
\hline & Grand Total & & 61.759 .128 .963 & 100 & 77.302 .110 .763 & 100 & 88.278.652.111 & 100 \\
\hline
\end{tabular}


kesehatan merupakan salah satu prioritas, sedangkan menurut informasi yang didapatkan dari informan pendanaan untuk Farmasi, alat kesehatan dan makan minum masih kurang walaupun jumlahnya tidak banyak.

Pada era Jaminan Kesehatan Nasional (JKN) Pelayanan kesehatan bagi peserta meliputi pelayanan kesehatan rawat jalan dan rawat inap, termasuk pelayanan obat dan Bahan Medis Habis Pakai (BMHP), oleh karena itu diperlukan aksesibilitas, keterjangkauan dan pengguanaan obat rasional. ${ }^{13}$

Program Kesehatan Masyarakat yang sebagian besar merupakan program prioritas, mendapat pendanaan pada Tahun 2014 sebesar 11,28\%, pada Tahun 2015 meningkat menjadi 15,74\% dan Tahun 2016 sebesar $13,96 \%$. Program Kesehatan Masyarakat seperti Program Kesehatan Ibu dan Anak (KIA), Gizi dan Keluarga Berencana mendapatkan pendanaan sebesar $5,47 \%-6,12 \%$. Jika dilihat target SPM pada pelayanan kesehatan Ibu dan Anak seperti cakupan kunjungan ibu hamil K4 Tahun 2015 sebesar 71,49 Tahun 2016 sebesar 68,90 dari target 90 . Cakupan pertolongan persalinan oleh tenaga kesehatan yang memiliki kompetensi kebidanan Tahun 2015 sebesar 86,10 , Tahun 2016 sebesar 86,15 dari target 90 . Cakupan pelayanan anak balita Tahun 2015 sebesar 47,12 Tahun 2016 sebesar 42 dari target 90 . Jika dilihat dari beberapa SPM di pelayanan KIA masih ada yang dibawah target capaian. Menurut informan pada Tahun 2014 sebelumnya bidan desa diberikan dana untuk sewa rumah anggaran dari APBD hal ini diberikan agar bidan desa bersedia tinggal di tempat dia bertugas, tapi program tersebut tidak berjalan lama.

Untuk Program Gizi mendapat dana di Tahun 2014 sebesar 0,57\% Tahun 2015 1,65\% dan Tahun 2016 sebesar 2,20\%. Setiap tahunnya program gizi mendapatkan peningkatan pendanaan. Jumlah ini menurut informasi yang disampaikan sudah mencukupi untuk program yang sifatnya wajib hanya untuk kegiatan yang sifatnya penunjang masih kurang. Capaian balita gizi buruk Tahun 2015 sebanyak 65 orang dan Tahun 2016 sebanyak 86 orang.

Pendanaan untuk program kesehatan lingkungan sebesar 0,66\%-3,31\% jumlah ini sudah mencukupi untuk program kegiatan kesehatan lingkungan seperti yang disampaikan oleh informan.

Pendanaan untuk program pencegah penyakit menular seperti untuk program TBC pada Tahun 2014 sebesar 0,11\%, Tahun 2015 sebesar 0,25\% dan tahun 2015 sebesar $0,1,23 \%$. Menurut informan, pada Tahun 2016 pendanaan untuk program DBD kurang, hak ini dikarenakan peningkatan kasus karena jumlah kasus meningkat, siklus 5 tahunan. Hal tersebut bisa diantisipasi dengan perencanaan yang baik. Dengan Perencanaan yang baik maka dapat memahami pentingnya dan mampu melakukan langkah-langkah analisis situasi serta memahami besaran dan peta persebaran masalah kesehatan. ${ }^{14}$ Menurut informan bahwa pendanaan untuk program TB masih kurang seperti yang disampaikan salah satu informan, masih banyak kegiatan yang belum terakomodir.

8. Gambaran Pembiayaan Kesehatan Menurut Mata Anggaran

Berdasarkan tabel 9 dapat dilihat bahwa belanja kesehatan di Kota Serang berdasarkan mata anggaran lebih banyak untuk belanja operasional yaitu sekitar $83,68 \%-93,57 \%$ dibandingkan untuk investasi sebesar $4,76 \%$ $8,26 \%$ dan untuk pemeliharaan sebesar $0,93 \%$ $-1,67 \%$. Belanja operasional kompensasi untuk pegawai memiliki porsi terbesar dari biaya operasional yaitu sekitar $48,04 \%-60,14 \%$ kemudian untuk belanja bahan dan jasa sekitar $24,94 \%-33,12 \%$.

Pembiayaan kesehatan untuk anggaran operasional mendapat porsi paling besar yaitu Pada Tahun 2014 sebesar 90,81\%

Tabel 9

Pembiayaan Kesehatan Menurut Mata Anggaran di Kota Serang Tahun 2014 - 2016

\begin{tabular}{llllllll}
\hline \multirow{2}{*}{ No } & \multirow{2}{*}{ Mata Anggaran } & \multicolumn{1}{l}{ Tahun } & \multicolumn{1}{l}{$l$} \\
\cline { 3 - 8 } & & $\mathbf{2 0 1 4}(\mathbf{R p})$ & $\mathbf{\%}$ & $\mathbf{2 0 1 5}(\mathbf{R p})$ & $\mathbf{\%}$ & $\mathbf{2 0 1 6}(\mathbf{R p})$ & \% \\
\hline 1 & HI.1 Investasi & 5.104 .308 .261 & 8,26 & 11.029 .852 .679 & 15,29 & 4.219 .410 .042 & 4,76 \\
2 & HI.2 Operasional & 57.658 .834 .868 & 90,81 & 64.690 .988 .084 & 83,68 & 82.576 .245 .569 & 93,57 \\
3 & HI.3 Pemeliharaan & 567.792 .500 & 0,93 & 781.270 .000 & 1,03 & 1.482 .996 .500 & 1,67 \\
\hline & Grand Total & $\mathbf{6 1 . 7 5 9 . 1 2 8 . 9 6 3}$ & $\mathbf{1 0 0}$ & $\mathbf{7 7 . 3 0 2 . 1 1 0 . 7 6 3}$ & $\mathbf{1 0 0}$ & $\mathbf{8 8 . 2 7 8 . 6 5 2 . 1 1 1}$ & $\mathbf{1 0 0}$ \\
\hline
\end{tabular}


Tahun 2015 sebesar 83,68 sebesar 83,68\% dan Tahun 2016 sebesar 93,57\%. Jika dilihat dari komponen belanja operasional paling banyak kompensasi untuk pegawai sekitar $49,2 \%$ - 60,14\%, komponen berupa gaji, honor, Jaminan kesehatan dan biaya lain terkait pegawai. Selanjutnya untuk belanja bahan dan jasa, terdiri atas belanja obatobatan, belanja Perjalanan dan Akomodasi, serta belanja bahan dan jasa lainnya seperti belanja perlengkapan, jasa konsultan. Belanja Perjalanan dan Akomodasi cukup tinggi hal ini senada dengan yang disampaikan oleh salah satu informan.

Belanja hibah atau bantuan sosial diberikan dalam bentuk iuran premi asuransi kesehatan yang diberikan kepada masyarakat Kota Serang yang miskin di luar kuota PBI pusat, jumlahnya setiap tahunnya mengalami peningkatan yaitu pada Tahun 2014 sebesar 3,76 Tahun 2015 sebesar $10,7 \%$ dan Tahun 2016 sebesar 10,93\%.

Belanja investasi mengalami peningkatan di Tahun 2016 hal ini dikarenakan rehabilitasi beberapa Puskesmas. Selain kontruksi, belanja investasi digunakan untuk Pengadaan alat non medis dan alat medis, serta pengadan kendaraan.

Belanja Pemeliharaan di Tahun 2016 mengalami peningkatan, komponen terbesar belanja pemeliharan adalah belanja pelatihan personil yang setiap tahunnya mengalami peningkatan. Hal ini sesuai dengan strategi yang ditetapkan oleh Kota Serang dalam RPJMD salah satunya peningkatan kualitas, kinerja, dan disiplin Aparatur Sipil Negara.

Keseimbangan antara mata anggaran adalah terpenuhinya pembiayaan pada setiap mata anggaran berdasarkan kebijakan Umum Anggaran (KUA) dan skala prioritas, jika pada KUA dan skala prioritas memementingkan perbaikan sarana dan prasarana kesehatan maka belanja modal menjadi lebih besar dan belanja operasional pemeliharaan menjadi penunjang. ${ }^{15}$

9. Komitmen Pemerintah Daerah

Dalam Undang-undang Nomor 23 Tahun 2014 Tentang Pemerintahan Daerah Pasal 67 disebutkan bahwa salah satu kewajiban kepala daerah dan wakil kepala daerah melaksanakan program strategis nasional, dimana yang dimaksud dengan program strategis nasional adalah program yang ditetapkan presiden sebagai program yang memiliki sifat strategis secara nasional dalam upaya meningkatkan pertumbuhan dan pemerataan pembangunan serta menjaga pertahanan dan keamanan dalam rangka meningkatkan kesejahteraan masyarakat. Salah satunya adalah program Nawa Cita Presiden Joko Widodo poin ke 5 (lima) yaitu "akan meningkatkan kualitas hidup manusia Indonesia melalui layanan kesehatan masyarakat". Dalam pasal 68 juga dijelaskan sanksi Kepala dan wakil Kepala Daerah yang tidak menjalankan program strategis nasional.

Dalam Rencana Pembangunan Jangka Menengah Daerah (RPJMD) Kota Serang tahun 2014 - 2018, sudah mengacu kedalam program strategis nasional dilihat dari Visi Kota Serang yaitu "Terwujudnya Kota Serang Madani sebagai Kota Pendidikan yang Bertumpu pada Potensi Perdagan, Jasa, Pertanian dan Budaya. Dari 5 (lima) misi Kota Serang salah satu misi yang berhubungan dengan sektor kesehatan adalah misi yang ke dua yaitu meningkatkan aksesibilitas dan kualitas layanan pendidikan, kesehatan dan layanan sosial lainnya dalam rangka meningkatkan kualitas hidup masyarakat. Salah satu upaya yang dilakukan di sektor kesehatan adalah dengan berupaya meningkatkan pendanaan kesehatan.

Komitmen pemerintah daerah terhadap pendanaan sektor kesehatan juga bisa dilihat dengan peningkatan proporsi pendanaan sektor kesehatan yaitu Tahun 2014 sebesar $6,02 \%$, Tahun 2015 sebesar $6,99 \%$ dan di Tahun 2017 sebesar 7,79\%.

Anggaran kesehatan perkapita Kota Serang setiap tahunnya mengalami kenaikan walaupun masih dibawah standar WHO yaitu sebesar US\$ 44 atau Rp 572.000. ${ }^{1}$

Berdasarkan penelitian sebelumnya yang mengenai Perencanaan Anggaran Kesehatan Melalui Kajian Pembiayaan Kesehatan Bersumber Pemerintah di Kabupaten Pidie Jaya, bahwa belanja kesehatan perkapita adalah sebesar Rp130.000 atau sebesar $10,58 \%$ dari APBD, ${ }^{9}$ Penelitian mengenai Pola Pendanaan Kesehatan Bersumber Pemerintah dan Komitmen Pemerintah Daerah Kabupaten Cirebon, bahwa anggaran kesehatan perkapita sebesar Rp Rp 83.611. ${ }^{10}$ 


\section{Kesimpulan}

a. Meningkatnya Anggaran Pendapatan Belanja Daerah (APBD) Kota Serang dari Tahun 20142016 diiringi dengan peningkatan anggaran kesehatan yaitu Tahun 2014 sebesar 6,02\%, Tahun 2015 sebesar 6,99\% dan di Tahun 2016 sebesar 7,79\%. Hal ini menunjukan adanya komitmen dari pemerintah daerah Kota Serang untuk terus berupaya meningkatkan anggaran kesehatan sesuai dengan ketentuan yang ditetapkan berdasarkan Undang-undang Kesehatan Nomor 36 tahun 2009.

b. Sumber Pembiayaan kesehatan di Kota Serang sebagian besar berasal dari APBD, dimana komponen APBD terbesar berasal dari komponen dana perimbangan yaitu sebesar 60,61\%-72,91\%. Sedangkan komponen APBD yang berasal dari Pendapatan Asli Daera (PAD) hanya sebesar 9,55\%-11,21\%, hal ini memperlihatkan bahwa kontribusi PAD terhada APBD masih rendah

c. Pembiayaan kesehatan berdasarkan fungsi, banyak untuk fungsi tata kelola sistem kesehatan kemudian untuk pelayanan kuratif.

d. Pembiayaan kesehatan berdasarkan program, banyak terealisasi untuk program penguatan Sistem kesehatan 59,55\%-67,43\% serta untuk program kesehatan individu sebesar 21,29\% $26,49 \%$ kemudian untuk program kesehatan masyarakat sebesar 11,28\%-13,96\%.

e. Pembiayaan kesehatan berdasarkan mata anggaran, paling besar untuk belanja operasional (83,68\%-93,57\%) untuk mata anggaran (4,76\%-15,29\%) serta untuk belanja pemeliharaan $(0,93 \%-1,67 \%)$

f. Berdasarkan hasilwawancara mendalam, faktor yang menentukan anggaran kesehatan adalah besarnya jumlah APBD serta program prioritas sesuai dengan RPJMD dan Renstra Kota Serang.

\section{Saran}

Adapun saran atau rekomendasi yang dapat diberikan peneliti terkait dengan pembiayaan kesehatan bersumber pemerintah di Kota Serang antara lain:

a. Agar adanya kesinambungan antara program prioritas dan pendanaan menurut program, sehingga program prioritas mendapatkan porsi pendanaan yang cukup, seperti untuk program kesehatan masyarakat yaitu program KIA, Gizi dan KB, program promosi kesehatan dan pencegahan penyakit. b. Perlu dibuat kebijakan penganggaran kesehatan sebagai dasar atau acuan perencanaan anggaran kesehatan di Kota Serang.

c. Meningkatkan pengetahuan dan kemampuan para pembuat program dan kegiatan di masingmasing bidang, sehingga dapat menganalisa dan merencanakan program dan kegiatan yang sesuai dengan target dan capaian

d. Dengan dana yang terbatas sedangkan banyaknya program kesehatan yang harus dilakukan maka dapat merencanakan program yang lebih efisien seperti dengan mengadakan program yang saling terintegrasi seperti program KIA terintegrasi imunisasi dan Gizi yang sudah berjalan, KIA terintegrasi dengan program penyakit menular dan promkes. Sehingga misalnya dalam kegiatan posyandu dapat dilakukan penyuluhan tentang penyakitpenyakit menular pada balita.

e. Agar dinas kesehatan dapat membuat tim khusus yang dapat membuat laporan DHA, sehingga laporan yang dibuat dapat dijadikan evidence untuk advokasi pembiayaan kesehatan di tahun berikutnya.

f. Meningkatkan peran dan fungsi perencanaan di Dinas Kesehatan, agar tidak hanya bersifat administratif dan koordinasi.

g. Agar adanya kesinambungan antara program dan kegiatan antar bidang dalam perencanaan kegiatan maka sebaiknya program dan kegiatan dibahas secara bersama antar semua bidang.

h. Bagi penelitian selanjutnya, agar dapat menganalisa belanja kesehatan secara keseluruhan baik dari sumber publik maupun pribadi sehingga dapat lebih menggambarkan secara keseluruhan mengenai pembiayaan kesehatan di Kota Serang.

\section{Daftar Pustaka}

1. WHO Gobal Health Expenditure Atlas, 2014 http:// www.who.int/gho/publications/world_health_ statistics/2016/EN_WHS2016_AnnexB.p.pdf?ua=1

2. Thabrany $\mathrm{H}, 2005$, Pendanaan Kesehatan dan Alternatif Mobilisasi Dana Kesehatan di Indonesia

3. Mills, Anne \& Gilson, Lucy, 1990, Ekonomi Kesehatan Untuk Negara-negara Sedang Berkembang. Penerbit Dian Rakyat-Jakarta

4. Lestari, 2003 Analisis Pembiayaan Kesehatan Daerah Bersumber Pemerintah di Kabupaten Tanggerang tahun 2003, Tesis Magister Kesehatan Masyarakat 
5. Murti, dkk 2006 Perencanaan Anggaran Untuk Investasi Kesehatan di Tingkat Kabupaten/ Kota, Yogyakarta, Gajah Mada University Press

6. BAPPEDA Provinsi Banten-PKEKK FKM UI, 2016, Penilaian Kualitas Belanja Daerah Urusan Kesehatan Provinsi Banten tahun 2015

7. Pemerintahan Kota Serang, 2016, Laporan Keterangan Pertanggungjawaban (LKPJ) Kota Serang Akhir Tahun Anggaran 2016

8. Yunaida, Luluk, 2010, Analisis Pendapatan Asli Daerah Kabupaten Tulungagung Pasca Diberlakukannya Otonomi Daerah https://www. researchgate.net/publication/50432532

9. Hasnur H, 2014 Perencanaan Anggaran Kesehatan Melalui Kajian Pembiayaan Kesehatan Bersumber Pemerintah di Kabupaten Pidie Jaya, Tesis Pasca Sarjana FKMUI

10. Rifttriani, Flora Devy, 2006, Pola Pendanaan Kesehatan Bersumber Pemerintah dan Komitmen Pemerintah Daerah Kabupaten Cirebon, Tesis Pasca Sarjana FKM UI

11. Peraturan Menteri Kesehatan Republik Indonesia Nomor 39 Tahun 2016 Tentang
Pedoman Penyelenggaraan Program Indonesia Sehat Dengan Pendekatan Keluarga

12. AIPHSS, 2013, Ketepatan Sistem Pembiayaan Kunci penting Pelayanan Kesehatan Yang Lebih Baik http://aiphss.org/id/ketepatansistem-pembiayaan-kunci-penting-pelayanankesehatan-yang-lebih-baik/

13. Kemenkes RI, 2015 Kebijakan Kefarmasian dan Alkes di Era JKN Dalam Koridor Implementasi UU No 23/2014 Tentang Pemerintah Daerah http://aiphss.org/wp-content/uploads/2015/05/ Kebijakan-Kefarmasian-dan-Alkes-di-Era-JKNmenurut-UU-no-23-tahun-2014.pdf

14. Departemen AKK FKMUI, Proses dan Metode Perencanaan Program Kesehatan Masyarakat. https://www.slideshare.net/dryohanita/prosesdan-metode-perencanaan-program-kesehatanmasyarakat

15. Harmana, Tisa, Adisasmito W, 2006, FaktorFaktor Yang Mempengaruhi Pembiayaan Kesehatan Daerah Bersumber Anggaran Pendapatan dan Belanja Daerah Tahun 2006, Jurnal Manajemen Pelayanan Kesehatan Vol 09 https://journal.ugm.ac.id/index.php/jmpk/ article/viewFile/2746/2468 diakses 9 Juni 2017 